\title{
Management Model of Energy Enterprises Innovative Development Within Physiological Working Conditions
}

\section{Modelo de gestión de empresas energéticas Desarrollo innovador en condiciones fisiológicas de trabajo}

\author{
Vasyl Brych \\ Doctor of Economic Sciences, Professor, Department of International Tourism and Hospitality Business \\ West Ukrainian National University. Ternopil, Ukraine. \\ ORCID: 0000-0002-4277-5213
}

Petro Mykytyuk

Doctor of Economic Sciences, Professor of Management, Public Administration and Personnel Department, West Ukrainian National University, Ternopil, Ukraine.

ORCID ID: 0000-0002-3038-6886

Nataliya Halysh

PhD in Economics, Department of International Tourism and Hospitality Business, West Ukrainian National University, Ternopil, Ukraine.

ORCID: 0000-0002-8538-823X

Olena Borysiak

$\mathrm{PhD}$ in Economics, Marketing Department West Ukrainian National University, Ternopil, Ukraine. ORCID: 0000-0003-4818-8068

\section{Ganna Zhekalo}

$\mathrm{PhD}$ in Politology, Associate Professor, Department of International Economy, Marketing and Management, West Ukrainian National University. Ternopil, Ukraine.

ORCID: 0000-0001-5125-2003

\section{Mariana Sokol}

Doctor of Pedagogical Sciences, Professor of Romanic-German Philology Department, Ternopil Volodymyr Hnatiuk National Pedagogical University. Ternopil, Ukraine.

ORCID ID 0000-0003-3876-026X

Received 09-08-20 Revised 10-10-20

* Correspondence

Email: v.brych@wunu.edu.ua
Accepted $12-12-20$ On line $03-18-21$

\section{Citation:}

Vasyl Brych, Petro Mykytyuk, Nataliya Halysh, Olena
Borysiak, Ganna Zhekalo, Mariana Sokol.
Management Model of Energy Enterprises
Development Winnovative
$\begin{aligned} & \text { Propósitos y Representaciones, 9 } \\ & \text { http://dx.doi.org/10.20511/pyr2021.v9nSPE3.1173 }\end{aligned}$

Vasyl Brych, Petro Mykytyuk, Nataliya Halysh, Olena Borysiak, Ganna Zhekalo, Mariana Sokol. (2021). Development Within Physiological Working Conditions http://dx.doi.org/10.20511/pyr2021.v9nSPE3.1173 


\begin{abstract}
This paper takes into account scientific approaches to mathematical modeling usage of interval data analysis to develop and improve the innovation management system due to effective innovative solutions related to the sale of energy resources and services including physiological working conditions of employees. The research outlines the tools for implementing the strategy of energy companies' innovative development based on dynamic interval management models of enterprises innovative development, which substantiate management decisions and correlates physiological working conditions of employees. As a result, all these factors make it possible to predict the impact of a system of innovative development factors on the enterprise financial condition. Construction methods of an integrated indicator level combined with workers physiological conditions of energy enterprises innovative development have been used and provided on the optimization of the factor space that creates the company's innovation policy and takes into account its causal links, human factor, physical level of readiness. The article results allowed its usage for modeling the impact of innovation level on the financial performance of energy companies as well as a study of the state of innovative development of energy enterprises in the region. The mathematical modeling has been used to build such a tool for managing the innovative development of energy market enterprises. One of the most effective approaches to modeling the dynamics of economic processes is the set-theoretic approach accompanied with physical level of employee. Within this approach, the models contain parameters and variables represented as sets of guaranteed or acceptable values, or as fuzzy sets with known matching functions. The paper determines that the advantage of this approach is that it does not require large samples of data (time series) to obtain adequate models, and preliminary study of statistical characteristics of data, such as the law of data distribution and others. The interval models, which describe indicators of economic processes in intervals of possible values or functional corridors, have been chosen as one type of models. It has been proposed to choose gross income as an indicator of the financial condition of energy market enterprises, because the activities of energy companies are essentially the sale of energy resources and services. Accordingly, innovative solutions aimed at improving sales should receive a response to gross sales revenue. The management mathematical dynamic models proposed in the work scientifically substantiate the decisions made and allow predicting the influence of the system of innovative development factors and physiological working conditions of employees on the financial condition of the enterprise.
\end{abstract}

Key words: physiological conditions, management model, innovative development, physical level.

\title{
Resumen
}

Este documento tiene en cuenta los enfoques científicos para el uso de modelos matemáticos del análisis de datos de intervalo para desarrollar y mejorar el sistema de gestión de la innovación debido a soluciones innovadoras efectivas relacionadas con la venta de recursos y servicios energéticos, incluidas las condiciones fisiológicas de trabajo de los empleados. La investigación describe las herramientas para implementar la estrategia de desarrollo innovador de las empresas energéticas basada en modelos de gestión de intervalo dinámico de desarrollo innovador de empresas, que fundamentan las decisiones de gestión y correlacionan las condiciones fisiológicas de trabajo de los empleados. Como resultado, todos estos factores permiten predecir el impacto de un sistema de factores de desarrollo innovadores en la situación financiera de la empresa. Se han utilizado métodos de construcción de un nivel de indicador integrado combinado con las condiciones fisiológicas de los trabajadores de las empresas de energía, el desarrollo innovador se ha proporcionado sobre la optimización del espacio de factores que crea la política de innovación de la empresa y tiene en cuenta sus vínculos causales, factor humano, nivel físico de preparación. Los resultados del artículo permitieron su uso para 
modelar el impacto del nivel de innovación en el desempeño financiero de las empresas de energía, así como un estudio del estado del desarrollo innovador de las empresas de energía en la región. El modelo matemático se ha utilizado para construir una herramienta de este tipo para gestionar el desarrollo innovador de las empresas del mercado energético. Uno de los enfoques más efectivos para modelar la dinámica de los procesos económicos es el enfoque de teoría de conjuntos acompañado del nivel físico del empleado. Dentro de este enfoque, los modelos contienen parámetros y variables representados como conjuntos de valores garantizados o aceptables, o como conjuntos difusos con funciones de coincidencia conocidas. El artículo determina que la ventaja de este enfoque es que no requiere grandes muestras de datos (series de tiempo) para obtener modelos adecuados, y estudio preliminar de las características estadísticas de los datos, como la ley de distribución de datos y otros. Los modelos de intervalo, que describen indicadores de procesos económicos en intervalos de valores posibles $\mathrm{o}$ corredores funcionales, se han elegido como un tipo de modelos. Se ha propuesto elegir los ingresos brutos como indicador de la situación financiera de las empresas del mercado energético, porque las actividades de las empresas energéticas son fundamentalmente la venta de recursos y servicios energéticos. En consecuencia, las soluciones innovadoras destinadas a mejorar las ventas deberían recibir una respuesta a los ingresos brutos por ventas. Los modelos dinámicos matemáticos de gestión propuestos en el trabajo sustentan científicamente las decisiones tomadas y permiten predecir la influencia del sistema de factores de desarrollo innovadores y las condiciones fisiológicas de trabajo de los empleados sobre la situación financiera de la empresa.

Palabras clave: condiciones fisiológicas, modelo de gestión, desarrollo innovador, nivel físico.

\section{Problem statement in general}

The system of innovation management is the basis of the management mechanism of all processes of direct or indirect influence of the innovation system at the micro or macro level in the field of energy service, as well as the main tool for achieving the goal and achieving all. It can be considered both as a separate management mechanism and as a subsystem of the innovation system, as well as an element of the overall management system of the company, organization or institution.

The managerial mathematical dynamic models are one of the tools of the innovation management system. They scientifically substantiate management decisions and allow predicting the impact of the system of innovative development factors on the financial condition of the enterprise.

A mathematical modeling has been used to build such a tool for managing the innovative development of energy within enterprises physiological working conditions of employees. The set-theoretic approach is one of the most effective approaches to modeling the dynamics of economic processes. Due to such conditions the models contain parameters and variables represented as sets of guaranteed or acceptable values, or as fuzzy sets with known matching functions (Brych V., Manzhula V. others, 2020, pp. 670-673).

The advantage of this approach is that it does not require large samples of data (time series) to obtain adequate models, and preliminary study of statistical characteristics of data, such as the law of data distribution and others.

The aim of the study is to propose a management model of energy enterprises innovative development within physiological working conditions.

The methodology of the research. The interval model of the dynamics of the financial condition index (gross profit) of energy companies within physiological working conditions in the western region of Ukraine is built in the form of a solution of 
discrete difference equations. The solution of equations system has been found by using methods of interval data analysis, which are based on two-way optimization practice of linear programming methods.

The main material of the research. It has been proposed to choose gross income as an indicator of the financial condition of energy enterprises within physiological working conditions, as the activities of energy companies are essentially sales of energy resources and services. Accordingly, innovative solutions aimed at improving sales should receive a response by gross income of sales. The interval representation of the values of the indicator of the financial condition of the company (gross income) will be:

$$
[G P]=\left(\begin{array}{l}
{\left[G P_{1}^{-} ; G P_{1}^{+}\right]} \\
\square \\
{\left[G P_{i}^{-} ; G P_{i}^{+}\right]} \\
\square \\
{\left[G P_{N}^{-} ; G P_{N}^{+}\right]}
\end{array}\right),
$$

where $G P_{i}^{-}=G P_{i}-\Delta, G P_{i}^{+}=G P_{i}+\Delta, \Delta \quad$ a limited error with a known range of possible values, or a functional corridor of such kind:

$$
\mathrm{GP}()=\mathrm{GP}-() ; \mathrm{GP}+() \text {. }
$$

The dynamic interval models have been used. They describe discrete difference equations as follows:

$$
G P_{n+1}=\alpha_{0}+\alpha_{1} \cdot G P_{n}+\sum_{i=1}^{M} \beta_{i} \cdot f\left(u_{i n+1}\right)
$$

where $n$-time discretion, $n=0, \ldots, N-1, N$ - number of dynamic series;

$G P_{n+1}$ - the value of the simulated index of the enterprise financial condition (gross profit) in $(n+1)$ - discrete;

$G P_{n}$ - the value of the financial index of the enterprise condition (gross profit) in $n$ - discrete moment of time;

$$
\vec{u}_{n}=\left(u_{1 n}, \ldots, u_{M n}\right)^{T} \quad-\text { vector of factors (management) including physiological }
$$
working conditions of employees on the index of financial condition of the enterprise (gross profit) in $n$ - discrete moment of time $i=1, \ldots, M$, where $M$ - the number of factors taken into account;

$$
\begin{aligned}
& \qquad\left(u_{i n+1}\right) \text {-basic functions in the form of polynomials; } \\
& \alpha_{0}, \alpha_{1} \text { - model coefficients; } \\
& \beta_{i}-\text { unknown coefficients of factors of enterprise in financial condition }
\end{aligned}
$$
management (gross profit).

Estimation of the model coefficients, given the opportunity to obtain interval calculation estimates of the studied indicators in the following form:

$$
\mathrm{GPn}+1=0+1 \mathrm{GPn}+\mathrm{f}(\mathrm{un}+1)
$$

where GPn+1,GPn - interval calculations of modeling indices of the financial condition of the enterprise; $0,1, \hat{\beta}^{-}$estimates of model coefficients and factors influencing the index of financial condition of the enterprise. 
Statistical data for 2016-2020 has been used for modeling. The value of $3 \%$ has been taken for the interval error and it corresponds to the error in the formation of statistical reference books.

As a factor in managing the financial condition of the enterprise, the indicators that reflect the main innovation cost have been taken:

$u_{n}$ _ the general coefficient of innovative development, which summarizes the investment in innovative solutions, where, $\mathrm{n}=0, \ldots, 4$ - period corresponding to 20162020.

An interval model of the dynamics of the index of financial condition (gross profit) of energy companies in the western region of Ukraine has been built and written in the form of discrete difference equations:

$$
G P_{n+1}=\alpha_{0}+\alpha_{1} \cdot G P_{n}+\dot{\beta} \cdot \dot{f}\left(u_{n+1}\right), n=0, \ldots, 4,
$$

where $G P_{n+1}$ - the value of the simulated index of financial condition (gross profit) in $(n+1)_{\text {_ }}$ series of dynamics and $G P_{n}$ - the value of the index of financial condition (gross profit) in $n_{-}$series of dynamics, $u_{n+1}-$ factors of influence (management) on the index of financial condition (gross profit), $\alpha_{0}, \alpha_{1}-$ model coefficients, $\dot{\beta}$ - vector of unknown coefficients of basic functions of the management factor of the enterprise financial condition index.

The model of dynamics is the following:

$$
\left\{\begin{array}{l}
{\left[G P_{1}\right]=\alpha_{0}+\alpha_{1} \cdot G P_{0}+\beta \cdot f\left(u_{1}\right)} \\
{\left[G P_{2}\right]=\alpha_{0}+\alpha_{1} \cdot G P_{1}+\beta \cdot f\left(u_{2}\right)} \\
{\left[G P_{3}\right]=\alpha_{0}+\alpha_{1} \cdot G P_{2}+\beta \cdot f\left(u_{3}\right)} \\
{\left[G P_{4}\right]=\alpha_{0}+\alpha_{1} \cdot G P_{3}+\beta \cdot f\left(u_{4}\right) .}
\end{array}\right.
$$

The solution of equations system has been carried out by using the methods of interval data analysis. They are based on a bilateral optimization using linear programming methods, under the following conditions:

$$
\begin{aligned}
&\left\{\begin{array}{l}
G P_{1}^{-} \leq \alpha_{0}+\alpha_{1} \cdot G P_{0}+\beta \cdot f\left(u_{1}\right) \leq G P_{1}^{+} \\
G P_{2}^{-} \leq \alpha_{0}+\alpha_{1} \cdot G P_{1}+\beta \cdot f\left(u_{2}\right) \leq G P_{2}^{+} \\
G P_{3}^{-} \leq \alpha_{0}+\alpha_{1} \cdot G P_{2}+\beta \cdot f\left(u_{3}\right) \leq G P_{3}^{+} \\
G P_{4}^{-} \leq \alpha_{0}+\alpha_{1} \cdot G P_{3}+\beta \cdot f\left(u_{4}\right) \leq G P_{4}^{+}
\end{array}\right. \\
& G P_{n} \in\left[G P_{n}^{-} ; G P_{n}^{+}\right], n=0, \ldots, 4 .
\end{aligned}
$$

where $G P_{i}^{-}=G P_{i}-\Delta, G P_{i}^{+}=G P_{i}+\Delta,{ }_{-}$lower and upper limits of the interval values of living standard and taking into account the statistical error.

Tables 3.1 show the original file of the factor of managing the financial condition of the enterprise, taking into account physiological working conditions of employees and index of financial condition of energy company PJSC "Lvivoblenergo". It has been reduced to an interval view with the aim to build a dynamic interval model.

Table 1. Initial data for building a dynamic interval model for PJSC "Lvivoblenergo" 


\begin{tabular}{|c|c|c|c|c|c|}
\hline \multirow{2}{*}{ Year } & \multirow{2}{*}{$n$} & \multicolumn{2}{|c|}{$\begin{array}{c}\text { Management factor including physiological working } \\
\text { conditions of employees }\end{array}$} & \multicolumn{3}{|c|}{ Interval limits of indicator financial } \\
\cline { 3 - 6 } & & $u_{n}$ & $G P_{0 n}$ & $G P_{n}^{-}$ & $G P_{n}^{+}$ \\
\hline 2016 & 0 & 0,74 & $-62,71$ & $-62,09$ & $-63,34$ \\
\hline 2017 & 1 & 0,49 & $-126,58$ & $-125,32$ & $-127,85$ \\
\hline 2018 & 2 & 0,45 & $-51,03$ & $-50,52$ & $-51,54$ \\
\hline 2019 & 3 & 0,48 & 64,30 & 63,65 & 64,94 \\
\hline 2020 & 4 & 0,90 & 159,94 & 158,34 & 161,54 \\
\hline
\end{tabular}

The interval system of linear algebraic equations has been written. The coefficients of the model are its solution. To obtain a model of dynamics, it is sufficient to get a solution in the form of a point in the solution area of this system. It is as following:

$$
\left\{\begin{array}{l}
-125,32 \leq \alpha_{0}-\alpha_{1} \cdot 62,71+\beta \cdot 0,49 \leq-127,85 \\
-50,52 \leq \alpha_{0}-\alpha_{1} \cdot 126,58+\beta \cdot 0,45 \leq-51,54 \\
63,65 \leq \alpha_{0}-\alpha_{1} \cdot 51,03+\beta \cdot 0,48 \leq 64,94 \\
158,34 \leq \alpha_{0}+\alpha_{1} \cdot 64,30+\beta \cdot 0,9 \leq 161,54
\end{array}\right.
$$

This system is an interval system of interval equations. In practice, this problem has been traditionally reduced to a nonlinear optimization problem. Its solution has been sought by linear programming methods and random search methods (Dyvak M., Porplytsya N., Brych V. others, 2019, pp. 354-357).

After estimating the coefficients of the interval model of gross profit dynamics for the enterprise PJSC "Lvivoblenergo", the following results in the form of a point model have been obtained:

$$
G P_{n+1}=381,75+1,06 \cdot G P_{n}-595,76 \cdot u_{n+1},
$$

In fig. 3.1. graphs of gross profit dynamics have been given on the basis of statistical data and on the basis of the dynamic model (3.10) during 2016-2020 for PJSC "Lvivoblenergo". The projected gross profit for 2020 is UAH 140.24 million.

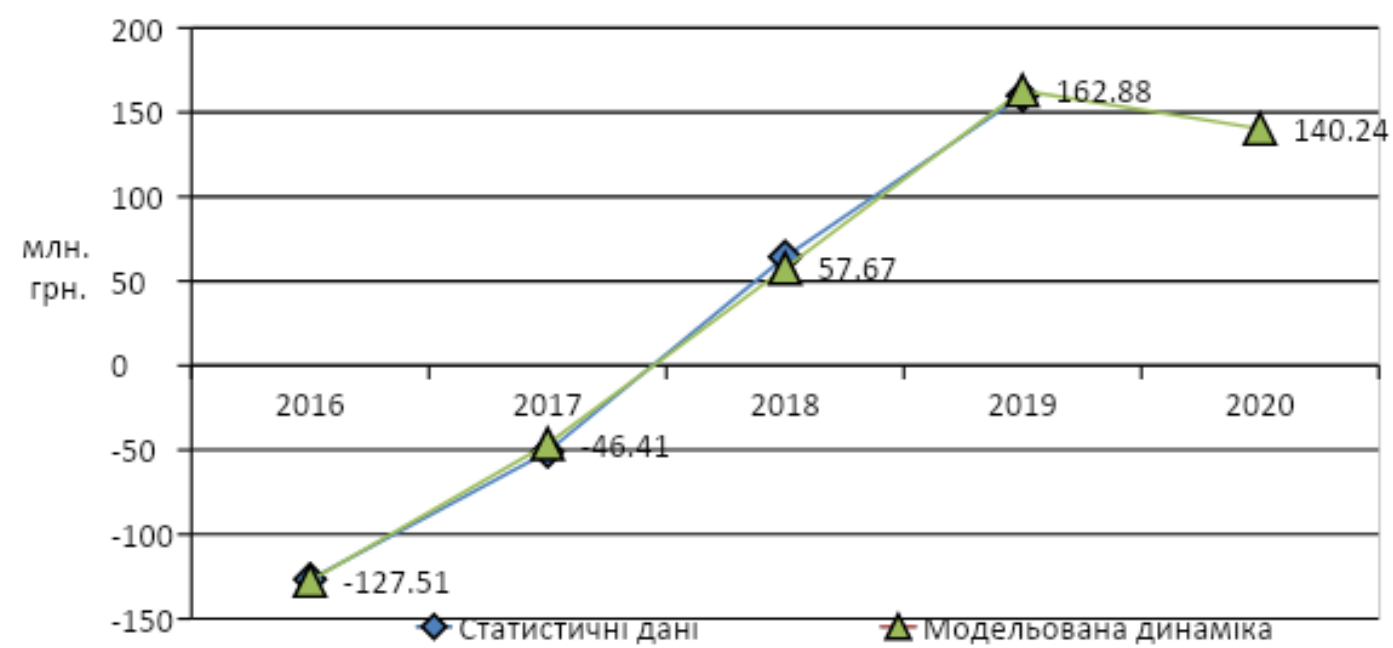

Fig. 1. graphs of gross profit dynamics on the basis of statistical data and on the basis of the dynamic model (3.10) during 2016-2020 for PJSC "Lvivoblenergo". 
Table 3.2 shows the initial data of management factor including physiological working conditions of the financial condition of the enterprise and the index of the financial condition of the energy company JSC "Ternopiloblenergo". It has been reduced to an interval view with the aim to build a dynamic interval model.

Table 2. Initial data for bouilding a dynamic interval model for JSC "Ternopiloblenergo

\begin{tabular}{|c|c|c|c|c|c|}
\hline \multirow{2}{*}{ Year } & \multirow{2}{*}{$n$} & \multicolumn{1}{|c|}{$\begin{array}{c}\text { Management factor including physiological working } \\
\text { conditions of employees }\end{array}$} & \multicolumn{3}{|c|}{ Interval limits of indicator financial } \\
\cline { 3 - 6 } & & $u_{n}$ & $G P_{0 n}$ & $G P_{n}^{-}$ & $G P_{n}^{+}$ \\
\hline 2016 & 0 & 0,85 & 82,10 & 81,28 & 82,93 \\
\hline 2017 & 1 & 0,64 & 78,85 & 78,06 & 79,64 \\
\hline 2018 & 2 & 0,81 & 158,67 & 157,08 & 160,25 \\
\hline 2019 & 3 & 0,93 & 141,10 & 139,69 & 142,51 \\
\hline 2020 & 4 & 0,87 & 116,18 & 115,02 & 117,35 \\
\hline
\end{tabular}

The interval system of linear algebraic equations has been written. The coefficients of the model are its solution. To get a model of dynamics, it is sufficient to find out a solution in the form of a point in the solution area of given system. It is as following:

$$
\left\{\begin{array}{l}
78,06 \leq \alpha_{0}+\alpha_{1} \cdot 82,1+\beta \cdot 0,72 \leq 79,64 \\
157,08 \leq \alpha_{0}+\alpha_{1} \cdot 78,85+\beta \cdot 0,4 \leq 160,25 \\
139,69 \leq \alpha_{0}+\alpha_{1} \cdot 158,67+\beta \cdot 0,66 \leq 142,51 \\
115,02 \leq \alpha_{0}+\alpha_{1} \cdot 141,1+\beta \cdot 0,86 \leq 117,35
\end{array}\right.
$$

Coefficients estimation of the interval model of the dynamics of gross profit for the company JSC "Ternopiloblenergo", gave the following results in the form of a point model:

$$
G P_{n+1}=176,7+0,63 \cdot G P_{n}-189,33 \cdot u_{n+1}^{2} .
$$

In fig. 3.1. graphs of gross profit dynamics have been given on the basis of statistical data and on the basis of the dynamic model (3.12) during 2016-2020 for JSC "Ternopiloblenergo". The projected gross profit for 2020 is UAH 109.44 million.

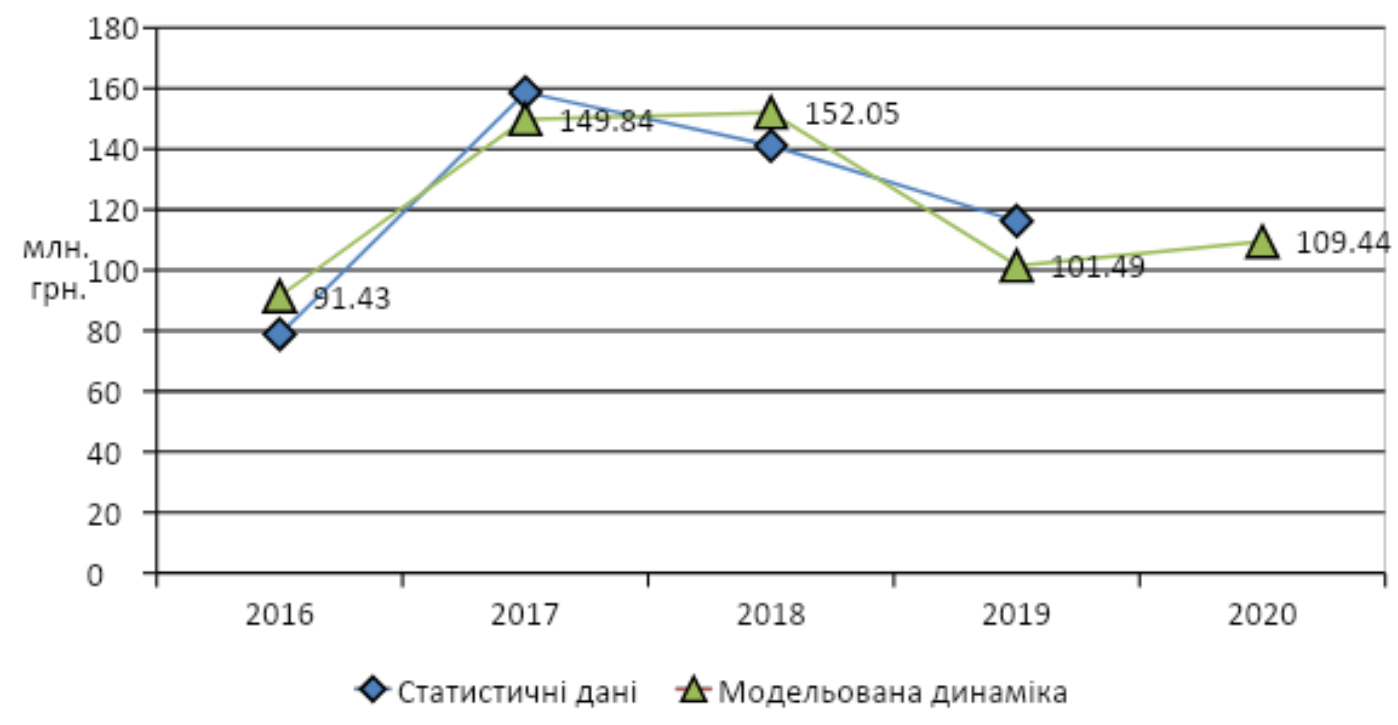


Fig. 2. graphs of gross profit dynamics on the basis of statistical data and on the basis of the dynamic model (3.12) during 2016-2020 for JSC "Ternopiloblenergo"

The calculations for the energy company JSC "Chernivtsioblenergo" have been done. Table 3.3. shows the initial data of management factor including physiological working conditions of the financial condition of the enterprise and the index of the financial condition of the energy company JSC "Chernivtsioblenergo". It has been reduced to an interval view with the aim to build a dynamic interval model.

Table 3. Initial data for building a dynamic interval model for JSC "Chernivtsioblenergo"

\begin{tabular}{|c|c|c|c|c|c|}
\hline \multirow{2}{*}{ Year } & \multirow{2}{*}{$n$} & \multicolumn{1}{|c|}{$\begin{array}{c}\text { Management factor including physiological working } \\
\text { conditions of employees }\end{array}$} & \multicolumn{3}{|c|}{ Interval limits of indicator financial } \\
\cline { 3 - 6 } & & $u_{n}$ & $G P_{0 n}$ & $G P_{n}^{-}$ & $G P_{n}^{+}$ \\
\hline 2016 & 0 & 0,82 & 51,93 & 51,41 & 52,45 \\
\hline 2017 & 1 & 0,88 & 13,44 & 13,31 & 13,58 \\
\hline 2018 & 2 & 0,97 & 89,76 & 88,87 & 90,66 \\
\hline 2019 & 3 & 0,54 & $-36,90$ & $-36,53$ & $-37,27$ \\
\hline 2020 & 4 & 0,88 & $-252,92$ & $-250,39$ & $-255,44$ \\
\hline
\end{tabular}

The interval system of linear algebraic equations has been written. The coefficients of the model are its solution. To obtain a model of dynamics, it is sufficient to get a solution in the form of a point in the solution area of this system. It is as following:

$$
\left\{\begin{array}{l}
13,31 \leq \alpha_{0}+\alpha_{1} \cdot 51,93+\beta \cdot 0,88 \leq 13,58 \\
88,87 \leq \alpha_{0}+\alpha_{1} \cdot 13,44+\beta \cdot 0,97 \leq 90,66 \\
-36,53 \leq \alpha_{0}+\alpha_{1} \cdot 89,76+\beta \cdot 0,54 \leq-37,27 \\
-250,39 \leq \alpha_{0}-\alpha_{1} \cdot 36,90+\beta \cdot 0,88 \leq-255,44
\end{array}\right.
$$

Coefficients estimation of the interval model of the dynamics of gross profit for the company JSC "Chernivtsioblenergo", gave the following results in the form of a point model:

$$
G P_{n+1}=-938,85-2,07 \cdot G P_{n}+1188,14 \cdot u_{n+1} .
$$

In fig. 3.3. graphs of gross profit dynamics have been given on the basis of statistical data and on the basis of the dynamic model (3.14) during 2016-2020 for JSC "Chernivtsioblenergo". The projected gross profit for 2020 is UAH 34.67 million. 


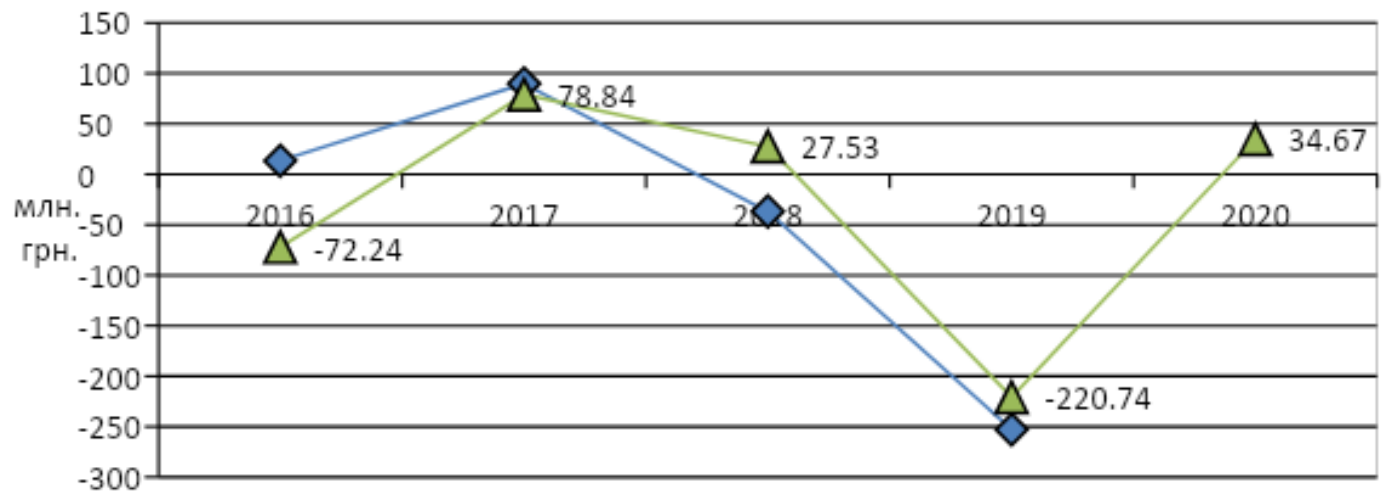

Статистичні дані $\triangle$ Модельована динаміка

Fig.

3. graphs of gross profit dynamics on the basis of statistical data and on the basis of the dynamic model

(3.14) during 2016-2020 for JSC "Chernivtsioblenergo"

To build a dynamic interval model for the energy company PJSC "Rivneoblenergo" has been summarized in table 3.4. It shows the initial data of management factor including physiological working conditions of employees and the index of financial condition that is reduced to the interval form.

Table 4. Initial data for building a dynamic interval model for PJSC "Rivneoblenergo"

\begin{tabular}{|c|c|c|c|c|c|}
\hline \multirow{2}{*}{ Year } & \multirow{2}{*}{$n$} & $\begin{array}{c}\text { Management factor including physiological working } \\
\text { conditions of employees }\end{array}$ & \multicolumn{3}{|c|}{ Interval limits of indicator financial } \\
\cline { 3 - 6 } & \multirow{2}{*}{$u_{n}$} & $G P_{0 n}$ & $G P_{n}^{-}$ & $G P_{n}^{+}$ \\
\hline 2016 & 0 & 0,57 & 39,69 & 39,30 & 40,09 \\
\hline 2017 & 1 & 0,90 & 32,22 & 31,89 & 32,54 \\
\hline 2018 & 2 & 0,80 & 147,48 & 146,01 & 148,96 \\
\hline 2019 & 3 & 0,80 & 109,66 & 108,56 & 110,76 \\
\hline 2020 & 4 & 0,96 & 199,50 & 197,51 & 201,50 \\
\hline
\end{tabular}

The interval system of linear algebraic equations has been written. The coefficients of the model are its solution. To obtain a model of dynamics, it is sufficient to get a solution in the form of a point in the solution area of this system. It is as following:

$$
\left\{\begin{array}{l}
31,89 \leq \alpha_{0}+\alpha_{1} \cdot 39,69+\beta_{1} \cdot 0,72+\beta_{2} \cdot 0,72 \leq 32,54 \\
146,01 \leq \alpha_{0}+\alpha_{1} \cdot 32,22+\beta_{1} \cdot 0,72+\beta_{2} \cdot 0,4 \leq 148,96 \\
108,56 \leq \alpha_{0}+\alpha_{1} \cdot 147,48+\beta_{1} \cdot 0,72+\beta_{2} \cdot 0,66 \leq 110,76 \\
197,51 \leq \alpha_{0}+\alpha_{1} \cdot 109,66+\beta_{1} \cdot 0,72+\beta_{2} \cdot 0,86 \leq 201,50
\end{array}\right.
$$

Coefficients estimation of the interval model of the dynamics of gross profit for the company PJSC "Rivneoblenergo", gave the following results in the form of a point model:

$$
G P_{n+1}=-6356,45-2,67 \cdot G P_{n}+18398,91 \cdot u_{n+1}-12288,76 \cdot u_{n+1}^{2} .
$$


In fig. 3.4. graphs of gross profit dynamics have been given on the basis of statistical data and on the basis of the dynamic model (3.14) during 2016-2020 for PJSC "Rivneoblenergo". The projected gross profit for 2020 is UAH 176.45 million.

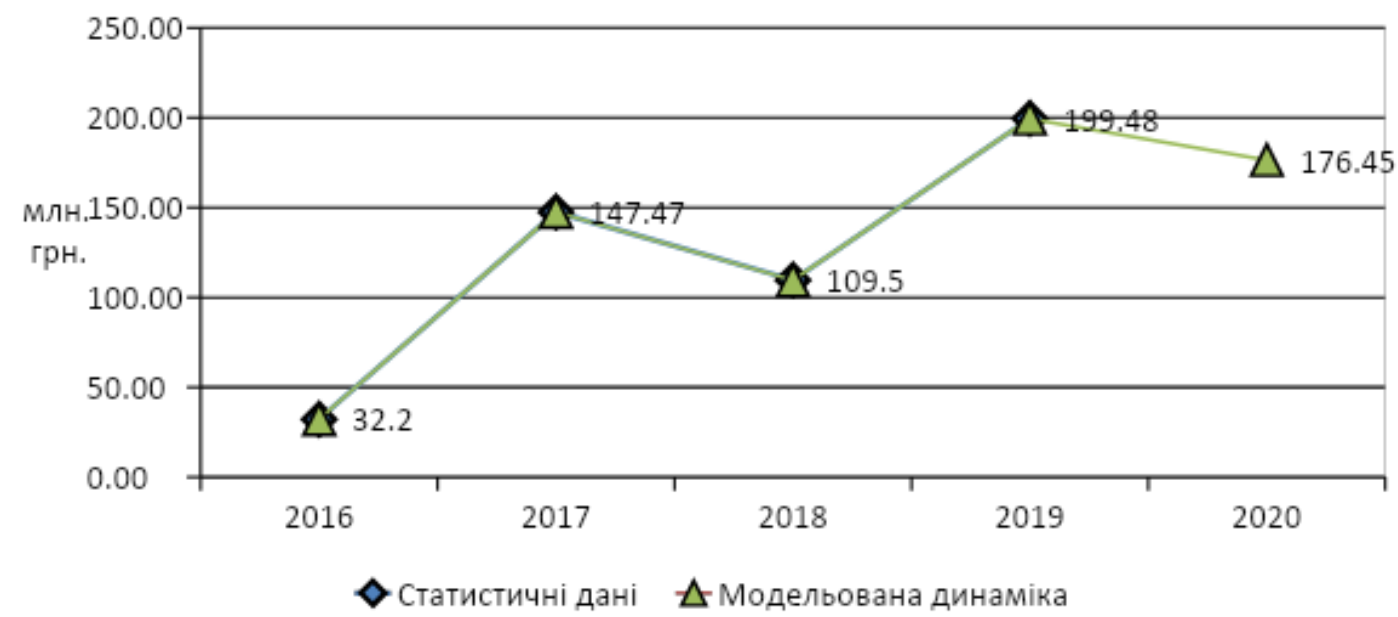

Fig. 4. graphs of gross profit dynamics on the basis of statistical data and on the basis of the dynamic model (3.16) during 2016-2020 for PJSC "Rivneoblenergo"

The calculations for the energy company PJSC "Volynoblenergo" have been provided. Table 3.5. outlines the initial data of management factor including physiological working conditions of the financial condition of the enterprise and the index of the financial condition of the energy company PJSC "Volynoblenergo". It has been reduced to an interval view with the aim to build a dynamic interval model

Table 5. Initial data for building a dynamic interval model for PJSC "Volynoblenergo"

\begin{tabular}{|c|c|c|c|c|c|}
\hline \multirow{2}{*}{ Year } & \multirow{2}{*}{$n$} & \multicolumn{2}{|c|}{$\begin{array}{c}\text { Management factor including physiological } \\
\text { working conditions of employees }\end{array}$} & \multicolumn{3}{|c|}{ Interval limits of indicator financial } \\
\cline { 3 - 6 } & & $u_{n}$ & $G P_{0 n}$ & $G P_{n}^{-}$ & $G P_{n}^{+}$ \\
\hline 2016 & 0 & 0,89 & $-5,673$ & $-5,61627$ & $-5,72973$ \\
\hline 2017 & 1 & 0,61 & 17,594 & 17,41806 & 17,76994 \\
\hline 2018 & 2 & 0,511 & 37,344 & 36,97056 & 37,71744 \\
\hline 2019 & 3 & 0,82 & 85,359 & 84,50541 & 86,21259 \\
\hline 2020 & 4 & 0,92 & 71,597 & 70,88103 & 72,31297 \\
\hline
\end{tabular}

The interval system of linear algebraic equations has been written. The coefficients of the model are its solution. To obtain a model of dynamics, it is sufficient to get a solution in the form of a point in the solution area of this system. It is as following:

$$
\left\{\begin{array}{l}
17,42 \leq \alpha_{0}-\alpha_{1} \cdot 5,67+\beta \cdot 0,61 \leq 17,77 \\
36,97 \leq \alpha_{0}+\alpha_{1} \cdot 17,59+\beta \cdot 0,51 \leq 37,72 \\
84,5 \leq \alpha_{0}+\alpha_{1} \cdot 37,34+\beta \cdot 0,82 \leq 86,21 \\
70,88 \leq \alpha_{0}+\alpha_{1} \cdot 85,36+\beta \cdot 0,92 \leq 72,31
\end{array}\right.
$$

Coefficients estimation of the interval model of the dynamics of gross profit for the company PJSC "Volynoblenergo", gave the following results in the form of a point model with linear component: 


$$
G P_{n+1}=99,82+0,6 \cdot G P_{n}-94,51 \cdot u_{n+1} \cdot
$$

In fig. 3.5. graphs of gross profit dynamics have been given on the basis of statistical data and on the basis of the dynamic model (3.18) during 2016-2020 for PJSC "Volynoblenergo". The projected gross profit for 2020 is UAH 55.52 million.

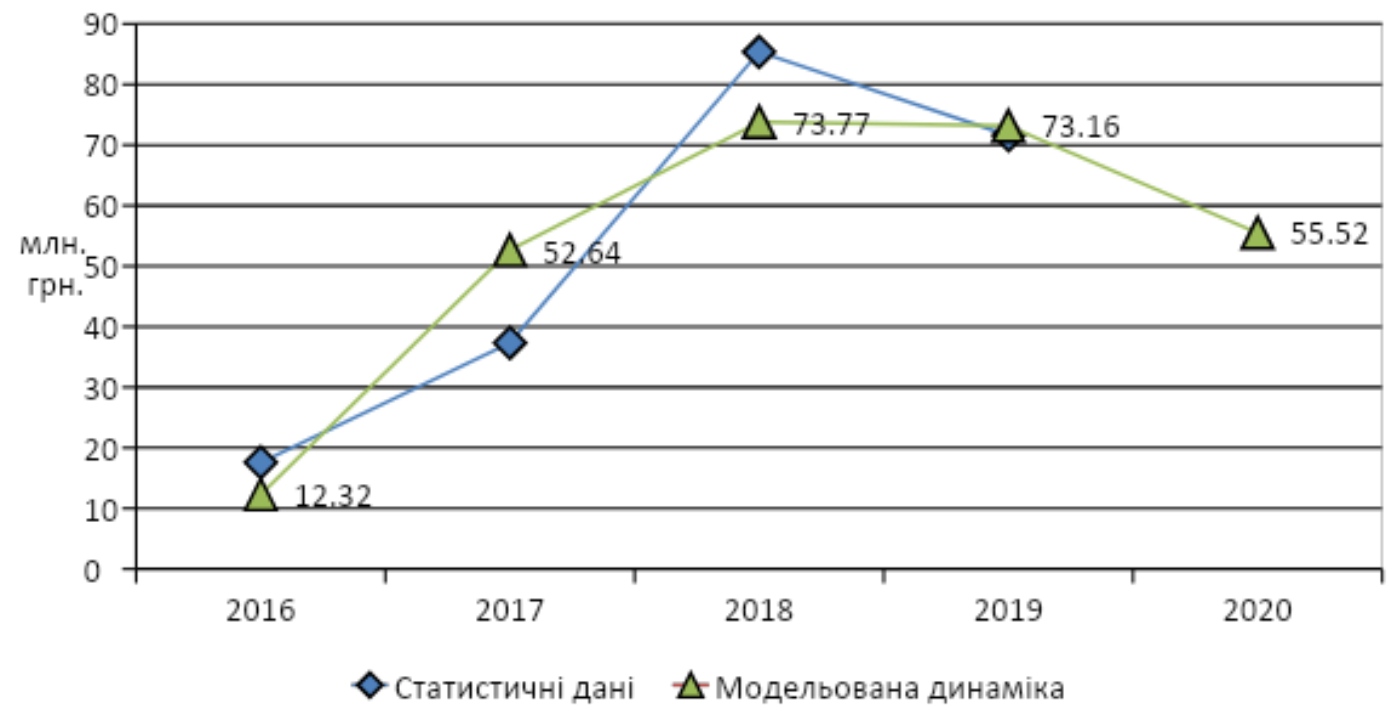

Fig. 5. graphs of gross profit dynamics on the basis of statistical data and on the basis of the dynamic model (3.18) during 2016-2020 for PJSC "Volynoblenergo"

\section{Conclusions and prospects for further studying}

The dynamic management model of innovative development of energy enterprises is aimed primarily at employees and their physiological working conditions. Mainly this aspect provides production processes in the power industry and improve the technical equipment of labor, the most efficient use of technological equipment and rational organization of the workplace. The management of enterprises should focus efforts on not only passing special training and testing of knowledge (certification) in accordance with the law. Therefore, it should include regulations of the ministry branches; ensure the implementation of the legal framework for the formation of state policy in the electricity sector, other central executive bodies that provide the formation of state policy in relevant areas.

Thus, mathematical models of the dynamics of the indicator of the financial condition of energy enterprises within physiological working conditions of Ukraine western region have been studied.

It has been proposed to choose gross income as an indicator of the financial condition of energy enterprises. Since the activities of energy marketcompanies are essentially the sale of energy resources and services. Accordingly, innovative solutions aimed at improving sales should receive a response to gross sales revenue.

Mathematical modeling has been used to build the tools of the management system of innovative development of energy enterprises within physiological working conditions. In particular, one of the most effective approaches, the theoretical-multiple (interval) approach, within which the models contain parameters and variables, presented in the form of intervals of guaranteed or acceptable values.

Dynamic models for managing the innovative development of energy market enterprises in the western region of Ukraine, namely: PJSC "Ternopiloblenergo", PJSC "Lvivoblenergo", JSC "Chernivtsioblenergo", PJSC "Rivneoblenergo" and PJSC "Volynoblenergo" have been obtained. The use of models makes it possible to predict 
the financial condition of the enterprise based on management decisions on innovation expenditures. In future researches it is planned to discover the innovation management system as a separate management mechanism in the system of innovation management, taking into account the physiological working conditions of European regions.

\section{References}

Brych V. Ya., Hevko B. R. (2016) Problems of application of solar energy in the sphere of housing and communal services. Innovative economy. 11 (1-2), 152-157. Ternopil:

Publishing.

URL:

file:///C:/Users/\%D0\%A0\%D0\%BE\%D0\%BC\%D0\%B0\%D0\%BD/Downloads/i nek 2016 1-2 26.pdf

Brych V., Manzhula V., Brych B., Halysh N., Ursakii Y., Homotiuk V. (2020) Estimating the Efficiency of the Energy Service Market Functioning in Ukraine. 10th International Conference on Advanced Computer Information Technologies (ACIT), 670-673. Germany: Deggendorf. URL: https://ieeexplore.ieee.org/document/9208858

Dyvak M., Porplytsya N., Brych V., Halysh N., Tulai O., Shpak Y. (2019) Modeling of Dynamics of the Company's Share in the Solid Fuel Market. 2019 9th International Conference on Advanced Computer Information Technologies (ACIT), 354-357. Czech Republic: Ceske Budejovice. URL: https://ieeexplore.ieee.org/document/8779973/authors\#authors 